\title{
$\begin{array}{lllllllllllllllll} & X & X & C & H & A & N & G & E\end{array}$
}

\section{Corporate Governance and Executive Remuneration: A Contingency Framework}

by Igor Filatotchev and Deborah Allcock

\section{Executive Overview}

By integrating organizational and institutional theories, this paper develops a contingency approach to executive remuneration and assesses its effectiveness in different organizational and institutional contexts. Most of the executive remuneration research focuses on the principal-agent framework and assumes a universal link between executive incentives and performance outcomes. We suggest a framework that examines executive compensation in terms of its organizational contexts and potential complementarities/ substitution effects between different corporate governance practices at both the firm and national levels. We also discuss the implications for different approaches to executive compensation policy such as "soft law" and "hard law."

0 ver the past two decades, companies around the world have increasingly moved from a fixed pay structure to remuneration schemes that are related to performance and include a substantial component of equity-based incentives. As a result, research on the economic effects of executive compensation has become one of the hotly debated topics within corporate governance research. As Bruce, Buck, and Main (2005, p. 1493) indicated, "In recent years, literature on executive remuneration has grown at a pace rivaled only by the growth of executive pay itself."

Most of the empirical literature on executive compensation has focused predominantly on the U.S./U.K. corporate sectors when analyzing organizational outcomes of different components of executive pay, such as cash pay (salary and bonus), long-term incentives (e.g., executive stock options), and perquisites (e.g., pension contributions and company cars). In terms of its theoretical underpinnings, previous research has attempted to understand executive compensation in terms of agency theory and explored links between different forms of executive incentives and firm performance.

This literature is motivated by the assumption that, by managing the principal-agency problem between shareholders and managers, firms will operate more efficiently and perform better. Much of corporate governance research is based on a universal model outlined by principal-agent theory (Fama \& Jensen, 1983; Jensen, 1986), and the central premise of this framework is that shareholders and managers have different access to firm-specific information, and broadly divergent interests and risk preferences. As a result, managers as agents of shareholders (principals) can engage in self-serving behavior that may be detrimental to shareholders' wealth maximization. A substantial body of literature is based on this straightforward premise and suggests that, to constrain managerial opportunism, shareholders may

* Igor Filatotchev (igor.filatotchev@city.ac.uk) is Professor of Corporate Governance and Strategy at Cass Business School, City University London, and Director of the Centre for Research on Corporate Governance.

Deborah Allcock (d.allcock@hud.ac.uk) is Senior Lecturer in Corporate Governance and Business Strategy the University of Huddersfield Business School, Queensgate, United Kingdom. 
use a diverse range of corporate governance mechanisms, including various equity-based managerial incentives that align the interests of agents and principals. As Jensen and Murphy (1990, pp. 242243 ) observed, "Agency theory predicts that compensation policy will tie the agent's expected utility to the principal's objective. The objective of shareholders is to maximize wealth; therefore agency theory predicts that $\mathrm{CEO}$ compensation policies will depend on changes in shareholder wealth." The key metric in effecting positive organizational outcomes is pay-performance sensitivity (Bruce et al., 2005).

However, this "closed system" approach, found predominantly within Anglo-American agencybased literature, posits a universal set of linkages between executive incentives and performance and devotes little attention to the distinct contexts in which firms are embedded. Despite considerable research effort, the empirical findings on these causal linkages have been mixed and inconclusive. For example, empirical studies and metaanalyses of the effects of executive equity-related incentives on financial performance have failed to identify consistently significant effects (see, for example, the surveys and commentaries of Core, Guay, \& Larcker, 2003; Daily, Dalton, \& Rajagopalan, 2003; Hall, 2003; and Tosi, Werner, Katz, $\&$ Gomez-Mejia, 2000). In a more recent critique of agency theory, Aguilera, Filatotchev, Gospel, and Jackson (2008) pointed out its "undercontextualized" nature and hence its inability to accurately compare and explain the diversity of corporate governance arrangements across different organizational and institutional contexts. Similarly, much of the resulting policy prescriptions enshrined in codes of "good" corporate governance rely on universal notions of best practice, which often need to be adapted to the local contexts of firms or translated across diverse national institutional settings (Aguilera \& Cuervo-Cazurra, 2004; Aguilera \& Jackson, 2003; Fiss \& Zajac, 2004).

In this paper we discuss an organizational approach to executive compensation that will better account for the interdependencies of incentive alignment with diverse organizational contexts and institutional environments. Building on re- search by Aguilera et al. (2008) we suggest that corporate governance aspects of executive compensation outlined by the agency and stakeholder perspectives must capture the patterned variation in corporate governance caused by differences in organizational contexts and their environment. Along these lines, we build on recent studies of corporate governance that have attempted to explain the dynamic dimensions of corporate governance over the company life cycle (Filatotchev \& Wright, 2005), as well as the diversity of corporate governance arrangements across countries (Aguilera \& Jackson, 2003; Bruce at al., 2005). Thus, an important task in corporate governance research is to uncover the diversity of arrangements and to understand how the effectiveness of executive remuneration is mediated by its alignment with situational variables ("context") arising in diverse organizational contexts and institutional environments (Aguilera et al., 2008).

We suggest a novel contingency-based framework for understanding the governance roles of executive compensation, which we conceptualize in terms of organizational context, complementarity/substitution between governance factors, and the impact of institutional environments. Organizational context refers to variations in firms' internal and external strategic resources and specific stages in their organizational life cycle (OLC). For example, older firms in the mature phases of their business life cycle may have a more diversified resource pool and "professionalized" management team. As a result, they may be in greater need of formal incentive alignment mechanisms compared to younger, founder-owned firms in their start-up phase, which may have narrower resource bases and thus higher focus on reputational, capability-related aspects of governance. Organizational context may affect not only potential benefits of executive compensation schemes, but also their costs, such as the direct costs of equity-based incentives and their indirect effects on managerial behavior and risk taking. These costs will vary for different firms operating in different sorts of environments, so that cost-benefit analyses are rarely universal. Complementarity/substitution refers to the overall "bundles" of corporate governance practices that are aligned with one another and 
mutually enhance the ability of those practices to achieve effective corporate governance. Here we argue that the effectiveness of executive compensation may depend on the presence of other governance factors, such as high shareholder involvement and board independence. Finally, institutions put a strong emphasis on social embeddedness and path dependence of executive compensation as a governance factor. Executive pay packages must be socially legitimate in relation to prevailing regulatory, normative, and cognitive impacts on organizations. As a result, these societal effects must be reconciled with organizational efficiency (Bruce et al., 2005).

\section{Principal-Agent Dichotomy Versus Organizational Approach to Executive Remuneration}

D rincipal-agent theory dominates research on managerial incentives, and it is primarily concerned with efficiency outcomes of executive compensation schemes from the perspective of shareholders, who invest resources and seek maximum return on their investment. This approach relies on the assumption of "arm's-length" contracting between shareholders and managers, and self-interested opportunism as a basis of their contracts (Bruce et al., 2005). Thus, besides attracting and retaining a high-quality management team, well-designed incentive schemes should increase corporate productivity and value by better aligning top managers' interests with those of shareholders (Hall, 2003).

Some studies, however, claim that executives, and particularly CEOs, enjoy positions of power in relation to the design of pay packages and are able to insulate themselves from constraints applied by regulators and shareholders. Self-interested executives may now extract rents by manipulating board structures in their own favor (i.e., by nominating their cronies as board members), subject mainly to an "outrage" constraint applied by the media (Bebchuk \& Fried, 2004). The CEO's pay arrangements, therefore, have less to do with incentive alignment and more to do with the CEO's self-enrichment or "skimming" (Bertrand \& Mullainathan, 2001). The extent to which sharehold- ers' agency problems are resolved and skimming prevented is typically assessed by associating executive pay with the performance of the firm (Buck \& Shahrim, 2005).

Empirical corporate governance research has begun to cast doubt on whether there is a direct and universal link between executive compensation and firm efficiency. Many have begun to question whether this association holds across the multiple variants of agency conflicts (Van den Berghe, Levrau, Carchon, \& Van der Elst, 2002); different organizational contexts such as entrepreneurial ventures, initial public offerings (IPOs), and mature firms (Filatotchev \& Wright, 2005); and different national settings. Perhaps more important is the fact that the performance impact of executive remuneration appears to differ with respect to the national institutional contexts. For example, studies of executive pay show strong correlations between pay and performance in the United States (Hall, 2003) and relatively lower effects of equity-based incentives in the United Kingdom and Germany (Bruce et al., 2005), whereas executive pay in Japan has no incentive effects (Kubo, 2005).

Meanwhile, studies in organization theory and strategic management suggest a number of alternative views on the governance roles of executive compensation. For example, stewardship theory has relaxed some of the assumptions about managerial behavior found in agency theory, arguing that managers may act as stewards for the good of the organization in situations where only relatively minor conflicts of interests exist (Davis, 2005). Likewise, stakeholder theory recognizes that the effectiveness of corporate governance factors depends on a wider set of firm-related actors and their interactions (Freeman, 1984), although this research has paid relatively less attention to executive incentives.

Despite their differences, a common tendency within these research streams is their reliance on universalistic models of efficiency, which abstract away from important organizational and environmental complexities (Aguilera et al., 2008). In agency theory, the "undercontextualized" approach remains restricted to mostly two actors (shareholders and managers), with little attention 
to how agency problems may vary across diverse task and resource environments, the life cycle of organizations, or different institutional environments. Although Williamson (1991, p. 277) suggested that transaction costs may be different in different institutional and organizational contexts, he pointed out that mainstream corporate governance research is "too preoccupied with issues of allocative efficiency ... to the neglect of organizational efficiency in which discrete structural alternatives were brought under scrutiny." Stewardship and stakeholder theory remove some restrictive assumptions of the agency approach, yet do not provide a comprehensive research framework that links executive incentives with the broader context of different organizational environments.

Following Aguilera et al. (2008) we propose that executive compensation research should adopt a more "open-system" approach, which treats organizational features as being interdependent with the diversity, fluctuations, and uncertainties of their environment, and rejects universalistic "context-free" propositions. In short, an open-system approach emphasizes the importance of examining executive compensation practices within a holistic context rather than as single factors acting in isolation.

Table 1 provides a summary of the main points of departure between the "traditional" agencybased approaches to executive compensation and our conceptual framework, which is grounded in organizational theory and synthesizes various empirical findings through a relatively parsimonious set of constructs. This approach is aimed at better understanding the interdependence between executive remuneration practices and the organizational and institutional environment in which these practices are conducted. These specific constructs are organizational context, complementarity/substitution with a corporate governance "bundle," and institutional effects. In short, we claim that the organizational effectiveness of executive incentives does not have a direct and linear effect on performance as suggested by mainstream agency research. This effect is contingent on a number of firm-level and macro factors that are, as a rule, not accounted for in the vast majority of studies. In the following sections we attempt to discuss these important contingency factors and their potential effects on the effectiveness and efficiency of executive compensation schemes.

\section{Organizational Context}

0 rganization theorists have examined how the effect of organizational ("structural") characteristics on effectiveness or performance may be mediated or influenced by contextual variables, such as task uncertainty, task interdependence, and organizational dynamics (Donaldson, 2001; Filatotchev, Toms, \& Wright, 2006). Although

\section{Table 1}

\section{Normative Principal-Agent Perspective vs. Contingency Framework of Executive Compensation}

\begin{tabular}{|c|c|c|}
\hline & Principal-Agent Model & Contingency Framework \\
\hline Organizational actors & $\begin{array}{l}\text { - Managers } \\
\text { - Shareholders }\end{array}$ & $\begin{array}{l}\text { - Managers } \\
\text { - Shareholders } \\
\text { - Stakeholders }\end{array}$ \\
\hline Organizational context & $\begin{array}{l}\text { - Focus on large, mature firms } \\
\text { - Focus on benefits of incentives, but also direct costs of } \\
\text { share options }\end{array}$ & $\begin{array}{l}\text { - Recognition of differences between } \mathrm{OLC} \text { stages } \\
\text { - Opportunity costs and reputational costs of } \\
\text { executive compensation }\end{array}$ \\
\hline Complementarity/substitution & $\begin{array}{l}\text { - Direct independent effect on performance } \\
\text { - Recognition of possible complementarities/substitution } \\
\text { with other governance factors }\end{array}$ & $\begin{array}{l}\text { - Incentives as component of governance } \\
\text { "bundles" } \\
\text { - "Equifinality" of governance effects }\end{array}$ \\
\hline National institutions & $\begin{array}{l}\text { - Context-free approach } \\
\text { - Focus on the U.S./U.K. environment }\end{array}$ & $\begin{array}{l}\text { - "Contextualization" of agency conflicts } \\
\text { - Focus on moderating effects of national } \\
\text { institutions }\end{array}$ \\
\hline Policy recommendations & $\begin{array}{l}\text { - Rules } \\
\text { - "Minimum standards" }\end{array}$ & $\begin{array}{l}\text { - Principles } \\
\text { - "Best practices" }\end{array}$ \\
\hline
\end{tabular}


executive compensation might be considered as a structural governance characteristic within this framework, organization theory has not elaborated with regard to the effectiveness of this form of corporate governance. Here we build on previous research and examine how the effectiveness of incentive mechanisms may be mediated by an important category of organizational contingencies, namely the resources and capabilities that shape firms' interdependences with different organizational environments (see Aguilera et al., 2008, for a more detailed discussion).

One aspect of resource-related contingencies is grounded in the resource-based view of the firm, which takes into account its resources and capabilities, such as skills, knowledge, and ability to innovate (Barney, 1991). A further aspect of resource-related contingencies comes from resource dependency theory, which suggests that firms will respond to demands made by external actors or organizations upon whose resources they are heavily dependent, but also that organizations may seek to buffer against or minimize that external dependence (Pfeffer \& Salancik, 1978). For example, the degree and nature of external finance is likely to influence the demands placed on corporate governance to ensure accountability and incentive alignment. Organizational context considerations thus imply that the role and effects of incentive schemes are likely to differ in ways contingent upon both the external and internal resources that are critical within the context of the firms' organizational, market, sectoral, or regulatory contexts. In other words, the effectiveness of executive incentives may depend on the firm's size or age, the phases of growth or decline in the company's development, and the character of innovation in different markets and sectors, among many other factors (Aguilera et al., 2008). While an organizational perspective rejects the notion of universal best practices (Donaldson, 2001), it also suggests that policy will be more effective if it takes into account the potential diversity of organizational contexts. In short, a one-size-fits-all approach is undesirable.

There is an increasing recognition in management research that the organizational resource base and its interdependence with external envi- ronments are not static, but an integral part of organizational dynamics. The application of a contingency-based concept of corporate governance has been developed within an emerging body of research on the life cycle of corporate governance (Filatotchev et al., 2006; Filatotchev $\&$ Wright 2005). This literature identifies a number of stages in the development of the firm and links them with changes in the extent and nature of agency conflicts that require governance remedies, including incentive alignment. Corporate governance is viewed here as a dynamic system whereby governance practices may address changing sets of environmental interdependencies throughout the different stages of the OLC, such as start-up, growth, maturity, and decline. Figure 1 F1 illustrates this theoretical framework.

Over the OLC stages, firms may evolve from having a very narrow resource base to having a more extensive and heterogeneous resource base. This transition may require at least temporary reliance on external resources. Providers of these external resources create new corporate governance demands to assure that wealth is not only created but also distributed fairly in terms of each factor provider, whether these are shareholders or other stakeholders. This is reflected in changes in accountability of the firm's management to external resource providers (Filatotchev et al., 2006).

In the early stages of the OLC (Quadrant 1 of Figure 1), the entrepreneurial firm has a narrow resource base. It is usually owned and controlled by a tightly knit group of founder-managers and/or family investors, with the level of managerial accountability to external shareholders generally low. In this context, a substantial portion of the founder-managers' wealth is linked to the firm, which questions the appropriateness or may even undermine the effectiveness of equity-based incentive schemes, in line with arguments developed by Core and Guay (2010).

As the firm grows, it requires access to external resources and expertise that may fuel and support this growth, and it opens up its governance system to external investors, such as business angels and venture capital firms. At this stage, the balance between resources and accountability starts to shift toward greater transparency and increasing 


\section{Figure 1}

\section{Organizational and Corporate Governance Dynamics}

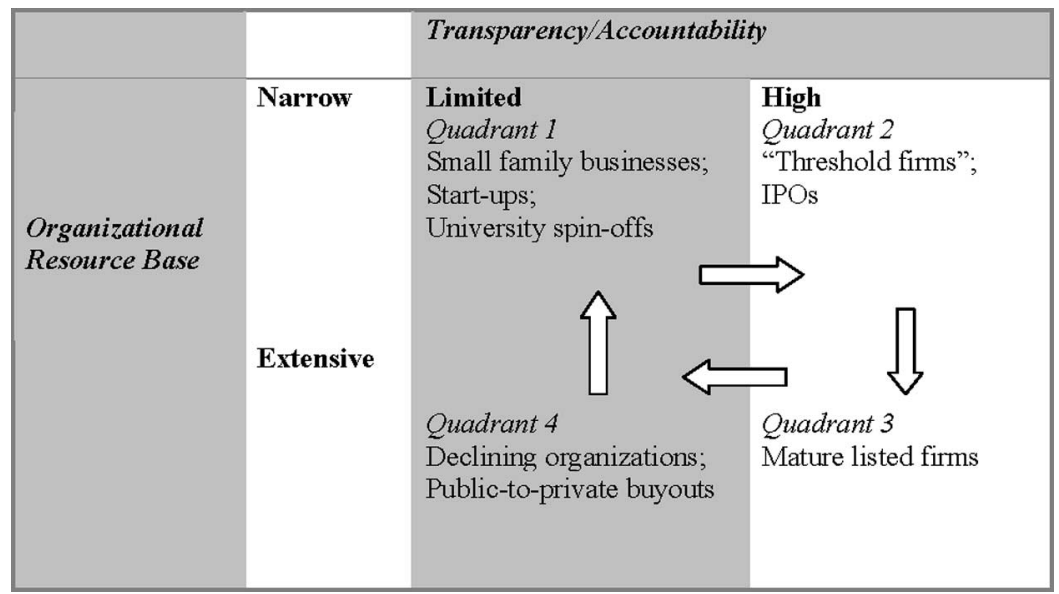

Source: Filatotchev, I., Toms, S., \& Wright, M. (2003). The firm's strategic dynamics and corporate governance life-cycle. International Journal of Managerial Finance, 2(4), 256-279.

monitoring by external providers of resources. An IPO (Quadrant 2 of Figure 1) represents a dramatic shift from an entrepreneurial firm to a "professional" firm with a fully developed governance system. The shift in accountability widens the firm's access to the financial resources of the stock market. In their analysis of executive compensation in IPO firms Allcock and Filatotchev (2009) identified an increasing role of executive share options as an emerging governance mechanism aimed at aligning interests of managers and incoming public market investors. However, they also identified a number of limitations imposed on this mechanism by the specific organizational context of IPO firms related to the continuing dominant role of the firm's founders in its governance system.

In the next stage, internal and external resources are invested in the firm's growth as it matures and exploits strategic opportunities (Quadrant 3 of Figure 1). When the firm has exhausted its growth opportunities in the focal industry and perhaps overdiversified into related and unrelated industries, the governance system becomes less transparent. Misalignment of incentives leads to a managerial drive for ever-increasing expansion and diversification, producing performance deterioration and loss in shareholder value. At this stage executives, and particularly CEOs, arguably enjoy positions of power in relation to the design of pay packages, and the CEO's pay arrangements may have less to do with incentive alignment and more to do with the CEO's self-enrichment or skimming (Bertrand \& Mullainathan, 2001). In a turnaround situation, executive remuneration schemes themselves may turn into a driver of further decline through their effects on managerial risk taking and time horizons (Wiseman \& Bromiley, 1996).

The only viable strategic alternative at this stage may be to take a public company private (Quadrant 4 of Figure 1). Restructuring of a declining organization following a public-to-private buyout may result in a reinvigoration of the life cycle as more transparent incentive and governance mechanisms are introduced in the form of increased managerial equity, monitoring by private equity firms, and a commitment to service debt. As such, the organization may narrow the scope of its activities and start a new cycle.

In sum, an effective incentive mechanism depends on patterned variations over the OLC, rather than conforming to a universalistic model. Organizational context underlines the "open" nature of organizational interdependence, such that, whereas mature firms may be concerned with reducing agency costs through incentive alignment, new entrepreneurial firms face different challenges in terms of making sure that founder-managers are able to anticipate future technological developments and growth opportunities as they 
try to buffer environmental uncertainties (Filatotchev \& Bishop, 2002).

The potential benefit of various governance practices is at the core of corporate governance research. However, Aguilera et al. (2008) argued that organizational context may also affect potential costs related to the inputs of corporate governance. These often appear as "externalities" or unintended consequences that stem from or are manifest in the broader environment of the organization and reduce the effectiveness of corporate governance. Such costs will vary across firms to the extent that they operate in different sorts of environments.

Executive compensation schemes may have associated costs of several types, starting with the direct costs that are reflected in the firm's balance sheet and other accounting documentation (Hall, 2003). In addition, incentive systems may impose less explicit opportunity costs (e.g., changes in managerial risk preferences) and reputational costs (e.g., costs of fraud, misconduct, or executive irresponsibility). These various costs may have different effects on the multiple parameters of incentive schemes' effectiveness, implying potential trade-offs between them.

Previous research is mainly focused on direct costs of various types of executive compensation, such as the out-of-pocket expenses associated with executive stock options (Oyer \& Schaefer, 2006; Ronen, 2008). The cost of executive stock options to shareholders can be estimated using the familiar Black-Scholes formula, though this may not be applicable to executive options that cannot be traded continuously thanks to vesting and holding periods (Hall \& Murphy, 2002). Notably, these costs differ according to different sectoral and national regulatory environments. An important implication is the differential impact of costs on firms depending on their resource capacities. For example, large firms with sufficient resources can more easily buffer these direct costs, while smaller firms with greater resource constraints may be unable to comply and may consequently face relatively high costs of executive bonding and incentive alignment (Aguilera et al., 2008).

Beyond these direct costs, executive compensation also entails less explicit and more indirect opportunity costs, which are often difficult to quantify (Hall, 2003). These costs relate to how an incentive mechanism affects managers' risk perceptions and strategic priorities and consequently the exploitation of business opportunities, and they may differ depending on the organizational context. For example, Hall and Murphy (2000) argued that, because executives in mature companies are forced by vesting requirements and insider share restrictions to hold more company equity than is desirable from a portfolio diversification perspective, they discount the value of their equity holdings. This "value-cost wedge" is the price that companies have to pay in order to generate the benefits of equity-based pay.

At the other end of the OLC spectrum, Allcock and Filatotchev (2009) examined the effects of opportunity costs associated with executive stock options in IPO firms. These authors integrated behavioral agency research (e.g., Wiseman \& Bromiley, 1996; Wiseman \& Gomes-Mejia, 1998) with "prospect theory" research (Kahneman \& Tversky, 1979) and suggested that executives' risk preferences and decisions may be driven by "problem framing," with their retained equity stakes after an IPO being an important factor affecting this framing. The lock-up restrictions on equity trading after the IPO may create transaction costs that prevent executives from adjusting their equity holdings to an optimal level. Therefore, using locked-up executive equity as a reference point for framing problems as gain or loss, the authors' behavioral model predicts that executives should exhibit risk-averse preferences when considering the appropriateness of different types of incentive schemes at an IPO.

Finally, executive compensation schemes may influence costs related to the reputation of the firm. For example, Hall (2003) and Buck \& Shahrim (2005) discussed problems of executive gaming or skimming associated with stock options. Equity-based pay, combined with the intense pressure to meet investors' expectations, can create unwanted consequences such as accounting manipulation or falsification of information aimed at boosting the stock price. As Hall (2003, p. 25) put it, "High-powered equity-based pay-particularly when combined with very short or no vesting 
restrictions - can encourage actions that are unethical and wasteful at best, and massively valuedestroying and fraudulent at worst." Some companies may be more vulnerable to reputation costs, such as auditing firms or banks, than firms that are traditionally less reliant on reputational capital, such as manufacturing firms. The important point is that the degree of direct, opportunity, or reputational costs associated with a particular compensation practice will affect different aspects of effectiveness, and their salience will vary across different organizational environments.

\section{Complementarities and Substitution Between Corporate Governance Factors}

0 ne of the central weaknesses in most executive compensation studies is the assumption that incentives and other types of corporate governance influencing performance are conceptualized and operationalized as independent and that each governance factor will have its own unique ability to influence the firm's strategies and performance. This supposition presumes that governance factors are both linear and additive to the extent that the effect of an internal or external governance attribute is the same regardless of the levels and combinations of other organizational attributes, or even the institutional conditions surrounding the company. However, the inconsistency of evidence across the spectrum of research on executive incentives suggests that the performance implications of a range of governance factors are a significantly more complex phenomenon than previously understood.

A growing literature has considered corporate governance as a system of interdependent elements by exploring how governance practices interact and potentially complement each other as related "bundles." Aguilera et al. (2008) developed this research further by focusing on complementarities between governance practices on a firm level, or interactions between practices and how these interactions align governance to potentially diverse organizational environments. An important implication of this research is that effectiveness does not result from a universal "one best way," but suggests that particular practices will be effective only in certain combinations. Furthermore, different sets of corporate governance practices may be further linked with costs and contingencies, as discussed in the previous sections, to understand how different patterns of corporate governance may give comparative advantages for different business strategies or industry environments.

A number of studies have made a first attempt to examine complementarity and substitution effects in terms of the combinations of corporate governance factors at the organization level. This research suggests that the simultaneous operation of multiple factors is important in limiting managerial opportunism (Rediker \& Seth, 1995; Walsh $\&$ Seward, 1990). For example, performance incentives for executives are more effective when complemented with an effective market for corporate control. These interdependent practices would remain quite ineffective without further complementary practices, such as high information disclosure to investors to allow the market to price shares accurately and a rigorous system of auditing to ensure the quality of that information.

This view is consistent with recent "set theoretic" approaches to studying organizational practices (Fiss, 2008) that focus on equifinality, whereby different initial conditions lead to similar effects or multiple conjunctural causation (Kogut, MacDuffie, \& Ragin, 2004; Ragin, 2000). In short, this framework helps explain why no one best way exists to achieve effective corporate governance. Rather, corporate governance arrangements are diverse and exhibit patterned variation across firms and their environments.

Among all potential combinations of corporate governance practices, the complementarity/substitution framework suggests that some combinations will be more effective than others. Indeed, recent literature has found more complex or surprising combinations of corporate governance variables, including executive compensation, than implied by early works that focused on a single effect of a particular incentive mechanism. For example, Hoskisson, Castleton, and Withers (2009) posited that there may be a dynamic interdependence between board monitoring and the extent of executive compensation. Contrary to 
conventional views, they argued that the increasing level of executive compensation may be explained not by failures in monitoring but rather by monitoring becoming increasingly intense due to the greater numbers of independent directors on the board and growing shareholder activism. Increased monitoring intensity shifts risk to managers, who then require greater compensation to offset their increased employment and career risk. The authors concluded that monitoring intensity is positively related to bonding so that over time they are complements.

While mapping such combinations is beyond the scope of this paper, the important analytical point here is that the effectiveness of executive compensation practices cannot be seen in isolation from other governance practices. In fact, these combinations may have opposite effects in different organizational contexts. In their analysis of executive share options in IPO firms, Allcock and Filatotchev (2009) showed that, contrary to the agency theory predictions, board independence does not have any effects on "toughness" of executive compensation in terms of conditions that have to be met. However, the retained ownership of venture capital firms is positively associated with the probability of performance-based incentive schemes. Again, this research indicates that executive compensation should be considered in relation to other governance characteristics of the firm.

\section{Executive Compensation and National Institutions}

A $s$ we indicated in the introduction, most of the empirical literature on executive compensation, specifically when analyzing organizational outcomes of different components of executive pay, has been focused predominantly on the U.S./U.K. corporate sectors. Meanwhile, many elements common in the Anglo-American model of corporate governance remain absent in other countries. Table 2 provides a breakdown of CEO compensation packages in the largest companies around the world, and it shows substantial differences among various countries. For example, in the United States, incentive plans account for the

\section{Table 2}

\section{Structure of CEO Remuneration Packages Around the World}

\begin{tabular}{|l|c|c|c|}
\hline \multicolumn{1}{|c|}{ Country } & $\begin{array}{c}\text { Base Salary } \\
(\%)\end{array}$ & $\begin{array}{c}\text { Cash Bonus } \\
(\%)\end{array}$ & $\begin{array}{c}\text { Incentive Plan } \\
\text { Compensation } \\
(\%)\end{array}$ \\
\hline United States & 23 & 17 & 60 \\
\hline Brazil & 27 & 41 & 32 \\
\hline Germany & 39 & 47 & 14 \\
\hline United Kingdom & 40 & 38 & 22 \\
\hline France & 44 & 25 & 31 \\
\hline Ireland & 44 & 43 & 13 \\
\hline Hong Kong & 51 & 19 & 30 \\
\hline Netherlands & 51 & 28 & 21 \\
\hline Belgium & 52 & 26 & 22 \\
\hline Italy & 52 & 29 & 19 \\
\hline Japan & 71 & 12 & 17 \\
\hline
\end{tabular}

Note: Companies with revenues between $\$ 1$ billion and $\$ 3$ billion.

Source: Watson Wyatt Worldwide. (2009). Executive pay practices around the world. London: Watson Wyatt.

lion's share $(60 \%)$ of total compensation, whereas base salary and cash bonuses account for just 23\% and $17 \%$ of the total, respectively. In Japan, however, $71 \%$ of the total executive compensation is related to base salary, with executive equity plans accounting only for $17 \%$. European countries are somewhere in between the two, with executive remuneration more evenly distributed among the three components.

There are marked differences among countries in terms of the total value of executive compensation. For example, Thomas (2008) reported results of a CEO pay survey around the world by Tower Perrin and showed that total CEO pay in Germany, Sweden, and China amounted to $51 \%$, $44 \%$, and $21 \%$ of CEO pay at comparable U.S. firms. Clearly, the structure and levels of executive compensation are very different around the world, and this may reflect significant institutional differences among countries.

A growing body of research argues that the efficiency and effectiveness of corporate governance factors, including executive compensation, should be considered within the context of national institutions (Bruce et al., 2005; Buck \& Shahrim, 2005). More generally, Schmidt and 
Spindler (2004) analyzed potential complementarities between various elements of national governance systems and suggested that various governance elements may complement each other in a consistent way to form path-dependent national systems within broader institutional and cultural contexts. Recent comparative work stresses the potential for organizational diversity within national economic systems, so that institutions may support certain types of organizations at the expense of others (Aoki, 2001; Aoki, Jackson, \& Miyajima, 2007; Williamson, 1991). National governance models have emerged as a key concept in comparative work on the diversity of national systems of corporate governance (Aguilera \& Jackson, 2003). A more recent organizational perspective on corporate governance (e.g., Aguilera et al., 2008) suggests that firm-level governance characteristics may be institutionally embedded. Therefore, the appropriateness and effectiveness of the specific incentive scheme may depend on the institutional context in which the firm operates and the extent of its conformity to the legitimized norms and expectations in that market.

Institutional theory provides an alternative explanation for firm behavior than that proffered by neoclassical economics, arguing that firm behavior can be understood in terms of shared beliefs of organizational actors, independent of their interests (DiMaggio \& Powell, 1983). Rather than make predictions based on utilitarian (e.g., economic) bases, institutional theory identifies social mechanisms that explain organizational behaviors. Consequently, strategic decisions that make rational, economic sense can fail to be understood from a more socialized perspective by examining those decisions vis-à-vis key stakeholders. Peng, Sun, Pinkham, and Chen (2009) used recent debates around executive compensation in the U.S. to illustrate this point. The competitive market for executive talent and the traditional tolerance for larger income inequality in the U.S. have fueled executive compensation. However, after 2008, during which many companies were bailed out or received substantial state support, the general sentiment with regard to executive compensation changed. Bounded rationality of the executives resulted in a failure to recognize changes in the informal (but powerful) norms concerning what was fair, thus attracting criticism from the media and the new president. So in addition to instrumental, economic considerations, the formulation of incentive strategy involves the need to provide justifications for decisions and behaviors that are considered legitimate by organizational stakeholders.

Understanding the differences in the institutional environments may help to develop a more comprehensive analysis of the effects of executive compensation in different countries in general, and explain striking differences in the pay-performance sensitivity around the world in particular (Buck \& Shahrim, 2005). North (1990) specified that formal institutions consist of laws and regulations, political and economic rules and procedures, and other explicit constraints on behavior. Alternatively, informal institutions consist of those unwritten, yet quite influential, societal norms, conventions, and values.

In the United States, stock-based executive compensation is so prevalent (Coombes \& Watson, 2001) that it has achieved "taken for granted status" (Sanders \& Boivie, 2004, p. 171) among financial and business community members. From an agency perspective, it would appear that U.S. investors place greater reliance on this monetary measure as the preferred incentive alignment mechanism. Its explicit nature, favorable tax treatment under the U.S. accounting rules, its assumption that managers are individuals solely motivated by self-interest and extrinsic rewards, make stock options a very appealing incentive system in the eyes of U.S. shareholders.

Outside the U.S. institutional context, executive share options often contradict prevailing culture, contingencies, and coalitions of interest (Bruce et al., 2005; Buck \& Shahrim, 2005). When investors rely on reputational considerations rather than formal equity-based incentives in evaluating the probability of self-serving behavior of managers, presence of executive share options would have relatively lower weight in terms of the firm's expected cost of capital.

In the United Kingdom, there is a considerable public debate with regard to incentive properties of executive share options. Since the late 1980s 
and early 1990s, many observers have found the dramatic increase in executive pay to be unjustifiable (Smith \& Szymanski, 1995). The general consensus has been that U.K. regulations have done little to address the issue of executive pay in detail. Instead, the main focus has been on disclosure and transparency. Studies comparing executive compensation in the United States and United Kingdom have found that the sensitivity of executive compensation to increases in shareholder wealth are much greater in the United States than in the United Kingdom, with the difference largely attributable to greater share option awards in the U.S. (Conyon \& Murphy, 2000).

Unlike in the United States and United Kingdom, in German and Japanese corporate governance systems, monitoring has been based on relationship-oriented banks rather than an active market for corporate control (Aoki, 2001). The long-term nature of bank-firm relationships may also complement a more active role for other stakeholders, such as employees, as employees' investments in firm-specific capital are protected from breaches of trust (Aoki, 2001). As a result, the applicability of equity-based incentives in these countries is generally restricted compared to the U.S., as clearly indicated in Table 2.

In our preceding discussion we emphasized the importance of considering complementarity and substitution among different governance practices on the firm level. Institutional analysis extends this framework further by suggesting that national institutions in general, and national governance models in particular, may shape the effectiveness of executive compensation. In economies characterized by diffuse share ownership, less significant roles of stakeholders, and higher tolerance to income inequality, one may expect executive incentives to play an important governance role by aligning interests of managers and shareholders (Hall, 2003). However, in societies with strong egalitarian tendencies, powerful stakeholders and reputational concerns that frame managerial behavior, the effectiveness of executive compensation may be limited regardless the specific organizational context.

\section{Implications for Future Research}

rounding analysis of executive compensation 7 in organizational theory has important implications for future research. Our approach to executive compensation suggests that the efficiency of different incentive schemes should be considered within the organization's context, such as stages in the OLC, level of business complexity, and strategic environment. For example, future studies may differentiate between the governance roles of incentives in diverse forms of organizations, such as entrepreneurial firms or multinational companies, which have often been overlooked in the governance literature. In addition, similarities and differences in incentive schemes can also be more systematically compared within and across industries, and recent controversy around bonus payments in financial institutions clearly indicates that industry context should be taken into account. Another area of research is related to potential organizational costs of executive incentives. Only a few studies have considered indirect opportunity costs associated with behavioral aspects and/or reputational concerns. Again, this research was predominantly focused on large, mature firms, and there is a dearth of studies in other contexts, such as entrepreneurial firms and IPOs (Allcock \& Filatotchev, 2009).

In addition, the vast majority of previous studies are focused on the economic effects of executive incentive schemes without taking into account potential interdependencies between various governance mechanisms. Hoskisson et al. (2009) provided a first attempt to discuss potential substitution/complementarity between executive compensation and board independence. Future research should look at other components of the firm's governance bundle, such as ownership structure and the identities of block holders, shareholder activism, and the firm's exposure to the market for corporate control. Recent advances within the set theoretic framework may be a useful research methodology able to operationalize and test more complex and context-dependent theories (Fiss, 2008; Ragin, 2000).

Finally, our discussion suggests that national institutional environments may affect the nature 
and extent of agency conflicts at the firm level, and the effectiveness of executive incentive schemes may depend on the specific institutional factors, such as laws and regulation, cultural aspects, and common beliefs of economic actors. Future research has to identify which institutional factors are more salient in terms of their effects on executive compensation within a comparative framework. For example, future studies may explore and compare the governance role of executive compensation in different national models of governance, including models based on family control (prevalent in emerging economies such as India) or the government (which plays an important role in Chinese and Russian companies).

\section{Regulatory Implications}

T he argument above for a more contextualized approach to executive compensation has implications for public policy. In the light of corporate governance scandals and perceived advantages in reforming governance systems, debates have emerged over the appropriateness of different policy approaches based on "hard law," or regulation that draws on "soft law" such as codes based on comply-or-explain principles (Thomas, 2009).

The hard law approach to regulation seeks to strengthen corporate governance through legal rules that cover all companies operating in a particular jurisdiction. Such an approach mandates high minimum standards, with failure to meet the standards resulting in severe legal penalties (Aguilera et al., 2008). In terms of executive compensation, advocates of a hard law approach suggest a set of rules, such as caps on the amount of executive pay, a mandated remuneration structure with increased amount of deferred shares, or even restrictions on the distribution of stock to executives, such as regulation of the firm's ability to issue new stock and/or stock buybacks (Thomas, 2009). In addition, disclosure regulations in many countries require corporations to introduce "sayon-pay" policies and reveal details concerning their executive compensation arrangements. The U.S. system has the most demanding set of rules in this regard.

Soft law is based on an alternative approach of comply-or-explain principles. It provides guidelines and best-practice principles for the determination of executive pay, which have been developed in various corporate governance codes promulgated recently. In the United Kingdom, listed companies can rely on detailed guidance on the design of performance-related compensation provided by the Combined Code on Corporate Governance. ${ }^{1}$ This approach has been criticized Fn1 for its weaker degree of enforcement and inability to mandate uniform minimum standards, but it has potential benefits in dealing with different organizational contingencies. Namely, the flexibility for firms to adapt or mix various corporate governance practices under soft law may help them to tailor corporate governance to diverse organizational environments.

It is beyond this paper's scope to provide a comprehensive evaluation of advantages and problems associated with the two approaches. Our analysis makes it clear, however, that each approach may be associated with regulatory tradeoffs, especially with regard to executive compensation. For example, it was hoped that a universal requirement to disclose the structure and level of executive compensation in the United States would slow the increase in executive pay, with the publicity about high pay working against abuses. However, Hall (2003, p. 32) argued that, "once executives began to see more clearly how much their peers were making, they wanted more-and boards granted more." Thus, while disclosure was generally aimed at curbing excesses, it also had unintended consequences by creating a fertile ground for abuses. In line with our analysis above, this example also suggests that executive compensation regulation should take into account other governance factors, such as the extent of board vigilance (Hall, 2003) and shareholder involve-

\footnotetext{
${ }^{1}$ The Combined Code on Corporate Governance sets out standards of good practice in relation to issues such as board composition and development, remuneration, accountability and audit, and relations with shareholders. All companies incorporated in the U.K. and listed on the Main Market of the London Stock Exchange are required under the Listing Rules to report on how they have applied the Combined Code in their annual report and accounts. Overseas companies listed on the Main Market are required to disclose the significant ways in which their corporate governance practices differ from those set out in the Code.
} 
ment in setting the structure and levels of pay (Thomas, 2009).

This discussion suggests that the regulatory trade-offs associated with different approaches to regulation of executive pay can be better understood by analyzing the implementation of policy in terms of organizational contexts, governance complementarities, and institutions. For example, U.K. regulators currently feel that codes need to be strengthened by greater legislative underpinnings to ensure enforcement. However, the fact that the U.K. approach is arguably the less universalistic and more contextualized may also help to explain why other countries on the whole have tended more to follow the U.K. Combined Code approach, defined above (Aguilera \& Cuervo-Cazurra, 2004). What is less clear is whether these countries have institutional characteristics similar to those of the United Kingdom combined with robust firm-level governance systems, which make sure that soft law has a significant impact on executive pay.

\section{Conclusion}

B uilding on the "open systems" approach to understanding organizations and their environments, this paper suggests a more contextualized framework that may be usefully applied to the analysis of executive compensation. Far from being comprehensive, it nevertheless draws attention to environmental interdependencies of corporate governance in terms of organizational context, complementarities, and substitution related to various well-known practices of corporate governance and the role of national institutions. In order to take systematic account of these factors in future empirical research, studies of executive compensation must explore the patterned variation of corporate governance practices, their combinations, and their effectiveness in terms of alignment of organizations with a more contextualized view of organizational environments.

\section{References}

Aguilera, R. V., \& Cuervo-Cazurra, A. (2004). Codes of good governance worldwide: What is the trigger? Organization Studies, 25, 415-443.

Aguilera, R. V., Filatotchev, I., Gospel, H., \& Jackson, G. (2008). An organizational approach to comparative cor- porate governance: costs, contingencies, and complementarities. Organization Science, 19(3), 475-492.

Aguilera, R. V., \& Jackson, G. (2003). The cross-national diversity of corporate governance: Dimensions and determinants. Academy of Management Review, 28(3), 447465.

Allcock, D., \& Filatotchev, I. (2009). Executive incentive schemes in initial public offerings: The effects of multiple agency conflicts and corporate governance. Journal of Management, doi:10.1177/0149206308329962. Available at http://jom.sagepub.com/cgi/content/abstract/ $0149206308329962 \mathrm{v} 1$.

Aoki, M. (2001). Toward a comparative institutional analysis. Cambridge, MA: MIT Press.

Aoki, M., Jackson, G., \& Miyajima, H. (2007). Corporate governance in Japan: Institutional change and organizational diversity. Oxford: Oxford University Press.

Barney, J. B. (1991). Firm resources and sustained competitive advantage. Journal of Management, 17(1), 99-120.

Bebchuk, L., \& Fried, J. (2004). Pay without performance: The unfulfilled promise of executive compensation. Cambridge, MA: Harvard University Press.

Bertrand, M., \& Mullainathan, S. (2001). Are CEOs rewarded for luck? The ones without principals are. Quarterly Journal of Economics, 116(3), 901-932.

Bruce, A., Buck, T., \& Main, B. (2005). Top executive remuneration: A view from Europe. Journal of Management Studies, 42(7), 1493-1506.

Buck, T. W., \& Shahrim, A. (2005). The translation of corporate governance changes across national cultures: The case of Germany. Journal of International Business Studies, 36, 42-61.

Conyon, M. J., \& Murphy, K. J. (2000). The prince and the pauper? CEO pay in the United States and United Kingdom. Economic Journal, 110, F640-F671.

Coombes, P., \& Watson, M. (2001). Corporate reform in the developing world. McKinsey Quarterly, 4, 89-92.

Core, J. E., \& Guay, W. R. (2010). Thinking about the relation between CEO wealth, incentives, and pay. Academy of Management Perspectives, this issue.

Core, J. E., Guay, W. R., \& Larcker, D. F. (2003). Executive compensation and incentives: A survey. Federal Reserve Bank of New York Economic Policy Review, 9(1), 27-50.

Daily, C., Dalton, D., \& Rajagopalan, N. (2003). Governance through ownership: Centuries of practice, decades of research. Academy of Management Journal, 46(2), 115158.

Davis, G. F. (2005). New directions in corporate governance. Annual Review of Sociology, 31(1), 143-162.

DiMaggio, P. J., \& Powell, W. W. (1983). The iron cage revisited: Institutional isomorphism and collective rationality in organizational fields. American Sociological Review, 48(2), 147-160.

Donaldson, L. (2001). The contingency theory of organization. Thousand Oaks, CA: SAGE.

Fama, E., \& Jensen, M. (1983). Agency problems and residual claims. Journal of Law and Economics, 26, 327349.

Filatotchev, I., \& Bishop, K. (2002). Board composition, 
share ownership and "underpricing" of U.K. IPO firms. Strategic Management Journal, 23(10), 941-955.

Filatotchev, I., Toms, S., \& Wright, M. (2006). The firm's strategic dynamics and corporate governance life-cycle. International Journal of Managerial Finance, 2(4), $256-$ 279.

Filatotchev, I., \& Wright, M. (Eds.). (2005). Corporate governance life-cycle. London: Edward Elgar.

Fiss, P. C. (2008). Case studies and the configurational analysis of organizational phenomena. In C. Ragin \& D. Byrne (Eds.), Handbook of case study methods (pp. 424440). Thousand Oaks, CA: SAGE.

Fiss, P. C., \& Zajac, E. (2004). The diffusion of ideas over contested terrain: The (non)adoption of a shareholder value orientation among German firms. Administrative Science Quarterly, December, 49(4), 501-534.

Freeman, R. E. (1984). Strategic management: A stakeholder approach. Boston: Pitman.

Hall, B. (2003). Six challenges in designing equity-based pay. Journal of Applied Corporate Finance, 15(3), 21-33.

Hall, B. J., \& Murphy, K. J. (2000). Optimal exercise prices for executive stock options. American Economic Review, 90(2), 209-215.

Hall, B. J., \& Murphy, K. J. (2002). Stock options for undiversified executives. Journal of Accounting and Economics, 33(1), 3-21.

Hoskisson, R. E., Castleton, M. W., \& Withers, M. C. (2009). Complementarity in monitoring and bonding: More intense monitoring leads to higher executive compensation. Academy of Management Perspectives, 23(2), $57-74$.

Jensen, M. C. (1986). Agency costs of free cash flow, corporate finance, and takeovers. American Economic Review, 76, 323-329.

Jensen, M., \& Murphy, K. (1990). Performance pay and top-management incentives. Journal of Political Economy, 98(2), 225-264.

Kahneman, D., \& Tversky, A. (1979). Prospect theory: An analysis of decision under risk. Econometrica, 47(2), 263292.

Kogut, B., MacDuffie, J. P., \& Ragin, C. C. (2004). Prototypes and strategy: Assigning causal credit using fuzzy sets. European Management Review, 1(2), 114-131.

Kubo, K. (2005). Executive compensation policy and company performance in Japan. Corporate Governance: An International Review, 13(3), 429-436.

North, D. (1990). Institutions, institutional change, and economic performance: Political economy of institutions and decisions. Cambridge, UK: Cambridge University Press.

Oyer, P., \& Schaefer, S. (2006). Costs of broad-based stock option plans. Journal of Financial Intermediation, 15(4), 511-534.

Peng, M. W., Sun, S. L., Pinkham, B., \& Chen, H. (2009). The institution-based view as a third leg for a strategy tripod. Academy of Management Perspectives, 23(3), 63-81.
Pfeffer, J., \& Salancik, G. (1978). The external control of organizations: A resource dependence perspective. New York: Harper \& Row.

Ragin, C. C. (2000). Fuzzy-set social science. Chicago: University of Chicago Press.

Rediker, K. J., \& Seth, A. (1995). Boards of directors and substitution effects of alternative governance mechanisms. Strategic Management Journal, 16, 85-99.

Ronen, J. (2008). Should executive options be expensed? Journal of Accounting, Auditing EF Finance, 23(3), 437470.

Sanders, G. W., \& Boivie, S. (2004). Sorting things out: Valuation of new firms in uncertain markets. Strategic Management Journal, 25(2), 167-186.

Schmidt, R. H., \& Spindler, G. (2004). Path dependence and complementarity in corporate governance. In J. N. Gordon \& M. J. Roe (Eds.), Convergence and persistence in corporate governance (pp.114-127). Cambridge, UK: Cambridge University Press.

Scott, W. R. (2003). Organizations: Rational, natural, and open systems. Englewood Cliffs, NJ: Prentice-Hall.

Smith, R., \& Szymanski, S. (1995). Executive pay and performance: The empirical importance of the participation constraint. International Journal of the Economics of Business, 2(3), 485-495.

Thomas, R. S. (2009). International executive pay: Current practices and future trends (Vanderbilt Law and Economics Research Paper No. 08-26). Nashville, TN: Vanderbilt University. Available at http://ssrn.com/abstract= 1265122.

Thompson, J. D. (1967). Organizations in action. New York: McGraw-Hill.

Tosi, H. L., Werner, S., Katz, J. P., \& Gomez-Mejia, L. R. (2000). How much does performance matter? A meta analysis of CEO pay studies. Journal of Management, 26(2), 301-339.

Van den Berghe, L., Levrau, A., Carchon, S., \& Van der Elst, C. (2002). Corporate governance in a globalizing world: Convergence or divergence? A European perspective. Boston: Kluwer Academic Publishers.

Walsh, J. P., \& Seward, J. K. (1990). On the efficiency of internal and external corporate control mechanisms. Academy of Management Review, 15(3), 421-458.

Watson Wyatt Worldwide. (2009). Executive pay practices around the world. London: Watson Wyatt.

Williamson, O. E. (1991). Comparative economic organization: The analysis of discrete structural alternatives. Administrative Science Quarterly, 36(2), 269-296.

Wiseman, R., \& Bromiley, P. (1996). Towards a model of risk in declining organizations: An empirical examination of risk, performance and decline. Organizational Science, 7, 524-543.

Wiseman, R., \& Gomez-Mejia, L. R. (1998). A behavioral agency model of risk taking. Academy of Management Review, 23(1), 133-153. 


\section{AUTHOR QUERIES}

